\title{
MILITARY PERCEIVED OVERQUALIFICATION IN A CIVIL ORGANIZATION
}

\author{
${ }^{1}$ Hondor Saragih, ${ }^{2}$ Yetti Supriyati, ${ }^{3}$ Sri Indah Nikensari, ${ }^{4}$ Ahmad Hidayat Sutawidjaya \\ hondorsaragih_7647158006@mhs.unj.ac.id, yetti.supriyati@unj.ac.id, indah_nikensari@unj.ac.id, \\ a.h.sutawijaya@mercubuana.ac.id
}

${ }^{1,2,3}$ Postgraduate Doctoral Program, Universitas Negeri Jakarta, ${ }^{4}$ Doctoral Program, Universitas Mercu Buana

\begin{abstract}
The Indonesian military is currently faced with a situation in the colonel's career bottleneck so that there is the potential for overqualification of military employees working in government institutions. This symptom can lead to the situation of early retirement for military employees in civilian settings. As many as 157 colonels and lieutenant colonels working at the Ministry of Defense of the Republic of Indonesia were involved in a study to find out how the perceived overqualification and leader-member exchange was independently related to job satisfaction and the early retirement intention. The results show that leader-member exchange has a positive effect on job satisfaction but has positive effect on early retirement intention. Meanwhile, the perceived overqualification affects only employee job satisfaction, not on early retirement intention. Job satisfaction influences early retirement intention. Even so, leader-member exchange does have a negative effect on perceived overqualification. Policies aimed at improving the quality of subordinate superiors' relationships are needed to prevent early retirement intentions of employees who experience overqualification.
\end{abstract}

Keywords: military employees, job satisfaction, early retirement intention, Ministry of defense, perceived overqualification

\section{Introduction}

Early retirement within the civil service is undesirable because it leads to loss of public returns (Bonke, Kemptner, \& Luthen, 2018) and has a detrimental effect on individual health (Wu, Odden, Fisher, \& Stawski, 2016). In countries where employment as a civil servant is a job that guarantees a good future and pensions like Indonesia, public employee turnovers are rare. However, when these benefits are certain to be obtained, turnover intentions can manifest through early retirement. In retirement, the employee has managed to get benefits and free to decide whether to stop immediately in the first years when they are allowed to retire or keep working until the maximum pension age is reached. Early retirement situations can be a manifestation of turnover intention because employees try to minimize their working period in public institutions.

Civil organizations with military members are unique settings to examine the situation of early retirement in public institutions. Military staff in civilian organizations can easily lose the motivation to work longer because of mismatch between the militaristic capabilities possessed with the civilian work environment. Meanwhile, these capabilities can be channeled to other places if good opportunities are available such as security services.

The Indonesian Ministry of Defense is an example of a civilian institution that has many employees from the military environment. Ministry of Defense staff data shows that there is an increasing tendency for the number of military employees who terminate their duties (due to defects or other things not mentioned) in 2015, 2016, and 2018. In 2015, seven people or $17 \%$ of the number of retired employees took early retirement. In 2016, this percentage dropped to $12 \%$ but was still quite high. In 2018, there were six out of 77 people or $8 \%$ of retired employees classified as early retirement by ending their duties. In fact, in 2015 and 2018, the number of early retired employees was higher than the number of employees who died (Ministry of Defense Personnel Bureau, 2018). 
Table 1 Indonesian Ministry of Defense Turnover 2013-2018

\begin{tabular}{lllll}
\hline Year & Turnover & Died & Early Retirement & Reason not Mentioned \\
\hline 2013 & 35 & 4 & 2 & 4 \\
\hline 2014 & 33 & 2 & 2 & 1 \\
\hline 2015 & 42 & 2 & 7 & 1 \\
\hline 2016 & 58 & 7 & 7 & 0 \\
\hline 2017 & 76 & 7 & 2 & 0 \\
\hline 2018 & 77 & 4 & 6 & 0 \\
\hline
\end{tabular}

Source: Ministry of Defense Personnel Bureau, 2018

In line with this, many echelon III / colonel employees, in accordance with the Decree of the Minister of Defense No. KEP / 08 / M / IX / 2001 regarding the Department of Defense's Position and Rank Consideration Agency (Defense Minister of Indonesia, 2001), have knowledge, skills, and experience that exceeds the requirements for their positions while still far from retirement age. They have a functional position (middle analyst), not structural position. In the Ministry of Defense, positions like this are called nonjob positions because they do not have productive routine jobs.

The situation of high early retirement in the Ministry of Defense can be a factor that causes governance problems that occur in the Ministry of Defense. The results of the performance accountability evaluation of government agencies by the Ministry of State Civil Servant and Bureaucratic Reform in 2014 and 2015 only gave B rating for the Ministry of Defense (Ministry of Home Affairs, 2017). B rating is relatively low rating because in general, government institutions get the BB and A categories. Category B means that accountability has just begun to be managed well to the level of the work unit. The results of performance accountability evaluation in 2016 show that the Ministry of Defense is still at the B rating, not shifting from the situation in 2014 and 2015 , while several other ministries, such as the Ministry of Social Affairs, Ministry of Women and Children Empowerment, Ministry of Communication and Information, Ministry of Health and the Ministry of State Owned Enterprises can move from category B to a higher category (Ministry of Home Affairs, 2017; Purnamasari, 2017).

The situation in the Ministry of Defense will, in turn, have a wider impact on the implementation of the functions of this ministry. Ministry of Defense is very important in order to realize a sovereign, independent and good Indonesia based on mutual cooperation, especially in the formulation, stipulation and implementation of policies in the areas of defense strategy, defense planning, defense potential, and defense power (Presidential Regulation No 58 Year 2015 on Ministry of Defense article 3(a)).

The Ministry of Defense is one of three ministries that are explicitly stated in the 1945 Constitution so that it is an integral part of the existence of this country. Not surprisingly, this ministry is one of the largest budget users. In the 2016 State Budget, the Ministry of Defense is the second largest ministry that uses the state budget, which is US\$ 7.5 Billion or $4.7 \%$ of total State Expenditures and $12.7 \%$ of Total State Expenditures for Ministries/Institutions, only defeated by the Ministry Civil Work and Public Housing (US\$ 8.0 Billion) (Akuntono, 2015). After the President issued Presidential Instruction No. 4 of 2016 concerning Measures for Saving and Cutting Ministries/Institutions Expenditures in the Context of the 2016 Budget Revenue and Expenditure Budget, the Ministry of Defense is the Ministry with the largest budget in 2016 (Indonesian President, 2016). In the 2017 and 2018 state budget, the Ministry of Defense is the ministry with the largest budget. In 2017, the budget for the Ministry of Defense reaches US\$ 8.4 Billion while in 2018 it reaches US\$ 8.0 Billion (Ministry of Finance Directorate General of Budget, 2018).

The situation in Ministry of Defense as described above has the potential to raise problems such as decreasing public returns and risk of mortality for retirees (Bonke et al, 2016; Wu et al, 2016). De Wind early retirement model shows that ability, motivation, and opportunity is the three main factors in encouraging employee retirement (de Wind, Geuskens, Ybema, Bongers, \& van der Beek, 2015). We argue that perceived overqualification is a variable that able to capture the three predictor variables of the employee's early retirement operationally. Perceived overqualification is very likely to occur with civilian institutions with the composition of military employees due to differences in background abilities with work. In fact, on the Indonesian Military own body, there is a surplus of colonel-ranking officers (Santoso, 2018). Recently, the Army Chief of Staff was forced to delegate around 368 mid-level officers, $90 \%$ of whom were colonels, fearing that there will be officers' career bottlenecks due to posts for higher officers were very limited while the number of colonels below them was very large. In line with this, we raise perceived overqualification as a determinant of early retirement in the Ministry of Defense.

In addition to this variable, we also use the quality of subordinate supervisors (Leader-Member Exchange - LMX) as a determinant of early retirement. LMX is "quality of the exchange relationship between supervisors and subordinates" (Y. Chen et al., 2015, p. 673). In the context of the Ministry of Defense, this includes relations between superiors and subordinates in the civil-military environment. Some military employees have civilian 
superiors with different leadership styles with the military, which can lead to the low quality of subordinate superior exchanges.

We also present the variable job satisfaction which is a common variable known to predict turnover intention. We propose that perceived overqualification and leader-member exchange will affect the job satisfaction of military employees, which in turn encourages them to intend to make early retirement in civilian institutions.

In line with the description above, the purpose of this study was to determine the effect of perceived overqualification and leader-member exchange on employee job satisfaction and its impact on the intention of early retirement of military employees in civilian institutions of the Indonesian Ministry of Defense. This research will provide theoretical and practical benefits. Theoretically, this study will expand the early retirement model that is still developing in the literature. Practically, this research will provide input for the Indonesian Ministry of Defense in reforming HR management within its organization to provide quality public services.

\section{THEORY AND HYPOTHESES}

Leader-Member Exchange (LMX)

LMX is "quality of the exchange relationship between supervisors and subordinates" (Y. Chen et al., 2015 , p. 673) Other definition states that LMX is "how leaders (managers and supervisors) maintain their position through a series of interactions with the members (subordinates) in an organizational hierarchy" (Kulkarni \& Ramamoorthy, 2014, p. 16). The definition from Kulkarni and Ramamoorthy implies that authoritarian interactions are acceptable, insofar as they can make leaders maintain their position. Moreover, the purpose of interaction more as a power relationship than intimate professional relationships through mutual trust. However, it can be argued that the best way to maintain relationships is to build mutual trust, mutual love, and mutual respect between superiors and subordinates.

The poor relationship between superiors and subordinates allows perceived overqualification to occur. This is caused by superiors not knowing the exact qualifications of employees due to lack of communication. If the supervisor does not know the qualifications of the employee, then the employee feels that things that are beneficial and can lift his achievements are ignored by the boss. This made him think that he was actually better, just that the boss didn't care. There are no studies that directly examine the effect of leader-member exchange on perceived overqualification. However, Liu dan Wang (2012) argue that perceived overqualification can be the result of a low leader-member exchange. This leads to employees trying to work harder to gain the trust of their superiors or integrate themselves with superiors to become group members. Yu, Matta, \& Cornfield (2018) suggest the potential for leader-member exchange can reduce perceived overqualification by focusing on the differentiation of leader-member exchange. Differentiation between superiors and subordinates is how subordinates judge the behavior of superiors in distinguishing subordinates. The theory of leader-member exchange states that superiors will divide the subordinates into two groups, subordinates who belong to the inner group and subordinates who belong to the outside group (Robbins \& Judge, 2017). This behavior can in turn make subordinates who are members of outside groups feel treated unfairly and make them feel overqualified. Therefore, it is hypothesized that..

Hypothesis 1: employee levels of Leader-member exchange will negatively influence their perceived overqualification.

Meng \& Wu (2015) provide empirical evidence that LMX can encourage employee job satisfaction in public institutions in China. A Singapore study also shows that LMX can encourage job satisfaction in employees in public sector organizations (Yeo, Ananthram, Teo, \& Pearson, 2015). The reason for this relationship is because employees who have a good and supportive boss will get positive emotions and feel satisfied with their work. Indonesia, Singapore, and China are countries in the Asian region that have strong cultural relations. Therefore, it will be possible if findings regarding the relationship of the LMX with job satisfaction in China and Singapore will also be found in Indonesia. This brings up the first hypothesis.

Hypothesis 2: employee levels of Leader-member exchange quality will positively influence their job satisfaction.

Good subordinate relations with their leader allow employees to commit to their work because they feel a positive return on their contribution to the organization. However, previous studies did not directly link LMX with turnover intention. Various mechanisms link LMX indirectly such as performance, job satisfaction, and organizational commitment (L. Li, Zhu, \& Park, 2018). However, there could be a direct relationship between LMX and turnover intention, it is hypothesized that:

Hypothesis 3: employee levels of Leader-member exchange quality will influence their early retirement intention.

\section{Job Satisfaction}

More recent research also confirms the negative effect of job satisfaction on intention to change employment. Shu, Gong, Xiong, and Hu (2018) found that non-family members working at family businesses 
experienced the intention to change jobs because of job dissatisfaction in a study of 121 family firms in China. Al Sabei et al. (2020) found that job satisfaction moderates the influence of the nurse's work environment on the intention to change employment in Oman. Meanwhile, Azeez, Jayeoba, dan Adeoye (2016) found that job satisfaction had an impact on decreasing intention to move, as did Huang, Chen, Liu, dan Zhou (2017) in their studies in China, Shah dan Lacaze (2018) which also involved Islamic work ethics variables, and Hwang dan Bae (2017) who studied the effect of job satisfaction on intention to change work in nurses in Korea. In line with this, Wang, Newman, dan Dipboye (2016) found that job satisfaction has a significant effect on intention to move work with job satisfaction influenced by job satisfaction of the employee's coworkers, implying a social transmission effect.

Therefore, based on the theoretical arguments and empirical evidence above, it is hypothesized that there is a negative direct effect of job satisfaction on intention to change employment and retired early.

Hypothesis 4 employee job satisfaction will influence their early retirement intention.

\section{Perceived Overqualification}

Overqualification is "a surplus of skills, education, and/or experience that are not required and/or being utilized by the current employment situation" (Dumani, 2016, p. 134). Overqualification is measured by the scale of perception and indicated by various things such as work requiring lower education than what is owned, previous training is not used fully in work, or someone with lower work experience can work well on the job (Maynard, Joseph, \& Maynard, 2006).

According to equity theory, human social behavior is influenced by confidence in the equal allocation of incentives in a group. That is, the output must be proportional to the contribution of group members. People are satisfied when their input and output ratios equal the ratios of others. Perceptions of inequality make people feel uncomfortable and motivated to reduce discomfort (S. Lee \& Whitford, 2007). Overqualification makes one feel that giving input is not equivalent to output. This will make social jealousy when he sees other people have a proportional ratio. This makes discomfort and leads to job dissatisfaction.

In line with the above arguments, a number of studies have found a relationship between perceived overqualification and job satisfaction. Benedict et al's study confirm that perceived overqualification have a negative effect on job satisfaction (Benedict, Gayatridevi, \& Velayudhan, 2009). Likewise, Green and Zhu's study studied overqualification, job dissatisfaction, and increasing dispersion in the return of post-graduate education (Green \& Zhu, 2008). They found that employees with real overqualification experienced job dissatisfaction, while employees with formal overqualification did not experience job dissatisfaction. Erdogan and Bauer's research on 244 sellers at 25 stores in Turkey revealed that perceived overqualification had a negative effect on job satisfaction, intention to stay, and a positive effect on intentional turnover (Erdogan \& Bauer, 2009). Johnson et al's research found that job satisfaction is negatively affected by perceived overqualification, meaning that the higher perceived overqualification, the more employees experience job dissatisfaction (Johnson, Morrow, \& Johnson, 2002). Maynard et al's study found a direct relationship between over-qualification and negative job satisfaction (Maynard et al., 2006) Feldman et al's study studied overqualification in relation to relative deprivation in executives rehired (Feldman, Leana, \& Bolino, 2002). The results of the study show that these executives experience low job satisfaction as a result of overqualification.

Hypothesis 5: employee levels of perceived overqualification will negatively influence their job satisfaction.

The theory of person-job fit indicates that the effects of perceived overqualification have similarities with the effects of perceived underqualification (Sim \& Lee, 2018). When an employee experiences overqualification, the employee feels there is a discrepancy between himself and his organization. This makes the employee have a negative attitude to the organization and wants to get a match elsewhere, which in turn results in turnover intention (Harari, Manapragada, \& Viswesvaran, 2017).

This reasoning is consistent with the results of previous studies that show that perceived overqualification is associated with high turnover intention (Harari et al., 2017; Yang, Guan, Lai, She, \& Lockwood, 2015). Using the view that early retirement intention is an analog of turnover intention on the background of public workers, the following hypothesis can be stated.

Hypothesis 6: employee levels of perceived overqualification will positively influence their early retirement intention.

\section{Leader-Member Exchange, Perceived Overqualification, Job Satisfaction, and Early Retirement Intention}

In de Wind et al (2015) theory, job satisfaction is seen as part of dedication which is a dimension of constructive work motivation. Employees with high job satisfaction will not be motivated to retire early because they are still satisfied with the work they have enjoyed. In line with this, job satisfaction has long been known to have an impact on early retirement (Topa, Depolo, \& Alcover, 2018).

In leader-member exchange literature, job satisfaction is generally seen as one of the main outcomes of leader-member exchanges (Breevaart, Bakker, Demerouti, \& van den Heuvel, 2015; Jyoti \& Bhau, 2015). LMX 
has an important role in increasing job satisfaction because employees feel treated well by their superiors (Liao, Wayne, Liden, \& Meuser, 2017). The meta-analysis study also shows that job satisfaction mediates the relationship between LMX and task performance and citizenship performance (R Martin, Guillaume, Thomas, Lee, \& Epitropaki, 2016). In particular, job satisfaction is also known to mediate the relationship between LMX and turnover intention (Han \& Jekel, 2011; L. Li et al., 2018).

Meanwhile, in the perceived overqualification literature, job dissatisfaction is also seen as a consequence of employees who feel overqualified (Deng et al., 2018; Hu et al., 2015; Yang et al., 2015). Dissatisfaction mainly occurs in career aspects because it relates to the achievements and future development of these employees (Erdogan, Tomás, Valls, \& Gracia, 2018; Kawai \& Mohr, 2017). This is because there are unmet needs that are expected to be generated from the excess ability possessed by employees (Debus, Gross, \& Kleinmann, 2019) coupled with the lack of support for employees to work at levels that are in accordance with their abilities (Hosoda, 2016). In line with this, it is also known that job satisfaction is a mediator between perceived overqualification and turnover intention (Harari et al, 2017).

If the leader-member exchange is able to bring about increased job satisfaction and perceived overqualification leads to a decrease in job satisfaction, and job satisfaction decreases turnover intention, then the leader-member exchange and perceived overqualification can be indirectly related to early retirement intention through its relationship with job satisfaction.

Hypothesis 7: Job satisfaction mediates relationships between leader-member exchange and the early retirement intention.

Hypothesis 8: Job satisfaction mediates relationships between perceived overqualification and the early retirement intention.

\section{METHOD}

Participants

The aim of the participant selection was to get active employees of the Ministry of Defense who had military status with the rank of colonel and lieutenant colonel. Employees of this rank are at the age of approaching retirement until retirement age so it is relevant to measure the intention of early retirement of these employees. However, there are not many employees with this rank in the Ministry of Defense. There are only 169 employees in the Indonesian Ministry of Defense who have this status. From requests given to employees to fill out questionnaires, only 157 questionnaires were returned, indicating a response rate of $93 \%$.

Men compiled $89 \%$ of the sample. Half of the samples have master's education. Overall, $31 \%$ of respondents have 20-24 years of service, $40 \%$ have 25-29 years of service, $26 \%$ have 30-34 years of service, and five $(3 \%)$ have 35-39 years of service. Eight percent of participants had the last military education in Diklapa (Officer Advanced Education), 46\% were educated in Diklapa plus (Officer Advanced Education Plus), 43\% were educated in the Staff and Command School of its Force (Army, Navy, or Airforce), and 2\% had the last education of Sesko TNI (Staff and Command School of Indonesian Armed Forces). There are two persons (1\%) have educational background in National Defense Agency (Lemhanas). Among respondents, 7.6\% were aged between 40-44 years, followed by $28.7 \%$ of the $45-49$ year age group, and the remaining $50-54$ years were $43.3 \%$ and $20.4 \%$ were aged between $55-59$ years. Note that the minimum retirement age for military officers (including colonel and lieutenant colonel) in Indonesia is 48 years and a maximum of 58 years (Government of Indonesia, 2010) and hence $63 \%$ of respondents in this study are eligible for retirement.

\section{MEASURES}

Leader-Member Exchange (LMX). We use a scale from Liden \& Maslyn (1998) which was modified into 31 items. Example items include: "My boss protects my work against higher employers, even without really knowing what is at issue", "My boss adjusts the policies he makes so as not to make it difficult for me to work"; "My boss can use the power he has to help me solve the problems I face"; "My boss will definitely help me out of trouble if I face a problem"; "The boss protects me if I am "attacked" by someone else"; "I usually know the position of the boss in my opinion"; "I usually know how satisfied the boss is with me"; and "I can usually guess what my boss will say if I do something". The choice of responses are strongly disagree, disagree, neutral, agree, and strongly agree.

Perceived Overqualification. We modified the perceived overqualification questionnaire from Fine \& Nevo's (2008) Perceived Cognitive Overqualification Questionnaire to 32 items. Response options ranging from strongly disagree to strongly agree on a 5-point scale. Examples of the items are "My work now requires lower skills than I have", " My work now requires less work experience than I have mastered", and "My work now requires a lower educational background than I have a travel".

Job satisfaction. We modified the scale of Bruck, Allen, \& Spector (2002) to 31 items scale. Examples of the items are "I am satisfied with the opportunity to be someone productive in society", "I am satisfied with the opportunity to use my own method of work", and "I am satisfied to be busy working all the time". 
Early retirement intention. We used a scale from Lee, Hung, \& Chen (2012) to be modified into 29 items to measure early retirement intention. Examples of the items are "In this heart, there is an opinion to move from Ministry of Defense", "I will move from of Ministry of Defense if I find an opportunity to work elsewhere", and "I think I will move to leave my colleagues in Ministry of Defense".

Control variables. Control variables are used to prevent statistical confounds. Controls in this research include age and organizational tenure.

\section{RESULTS}

The results of the Exploratory Factor Analysis (EFA) on all items analyzed showed a total of 22 factors with eigenvalues greater than 1 (total number of variants explained $=77.75 \%$ ). Factor 1 accounted for $27.56 \%$ of variance, followed by the four largest factors which accounted for $11.99 \%, 6.50 \%, 5.09 \%$, and $3.55 \%$. Because the first factor did not explain the majority of variants $(27.56 \%<50 \%)$, the general method bias was not a problem in this study.

Descriptive statistics, internal consistency estimates, and Pearson product-moment correlations are presented in Table 1. Structural equation modeling is used to test all hypotheses. Control variables can be included if the variable is related to two other variables hypothesized to be related. Table 1 shows that all control variables do not meet these criteria. Because it does not meet the requirements, the control variables are not included in the structural equation modeling. This will also conserve the degree of freedom in the analysis.

Tabel 1. Descriptive statistics, estimasi konsistensi internal, dan korelasi produk-momen Pearson $(\mathbf{N}=$ 157)

\begin{tabular}{lrrrrrrrr}
\hline & M & \multicolumn{1}{c}{ SD } & \multicolumn{1}{c}{1} & \multicolumn{1}{c}{2} & 3 & 4 & 5 & 6 \\
\hline 1. Age & 50.67 & 4.36 & $\mathrm{n} / \mathrm{a}$ & & & & & \\
2. Tenure & 27.33 & 3.83 & .82 & $\mathrm{n} / \mathrm{a}$ & & & & \\
3. Early retirement intention & 2.15 & .86 & .03 & .07 & .96 & & & \\
4. LMX & 3.86 & .69 & -.05 & -.02 & -.06 & .95 & & \\
5. Perceived overqualification & 2.31 & .91 & .14 & $.17^{*}$ & $.45^{* *}$ & $-.30^{* *}$ & .96 & \\
6. Job satisfaction & 3.80 & .83 & -.03 & -.08 & $-.33^{* *}$ & $.66^{* *}$ & $-.46^{* *}$ & .96 \\
\hline
\end{tabular}

Note. * significant at $p<.05 ; * *$ are significant at $p<.01$. Internal consistency estimates (Cronbach's alpha) are reported in italics in the diagonal where applicable. $\mathrm{n} / \mathrm{a}=$ not applicable; $\mathrm{LMX}=$ leader member exchange

Confirmatory factor analysis is performed to find the validity and reliability of the scale. The results of the confirmatory factor analysis revealed that a number of items had a loading factor of less than 0.7 . These items are omitted from subsequent calculations. The following table reports the construct reliability (CR) and average variance extracted (AVE) of each research variable. All CR values indicate values above 0.7 , which are between 0.95 and 0.96 , so that basically confirms good reliability. Even so, all AVE values are less than 0.5 which is the threshold for AVE. According to Fornell and Larcker (1981), AVE in the range of 0.40 is still acceptable as long as the composite reliability (CR) shows a value of more than 0.60 . Because CR shows a value of 0.956 , AVE 0.449 is still acceptable. This shows that the instrument has good reliability and validity.

\section{Tabel 2 Confirmatory Factor Analysis (CFA)}

\begin{tabular}{lll}
\hline Construct Measured & Construct Reliability (CR) & Average Variance Extracted (AVE) \\
\hline Early retirement intention & .96 & .45 \\
LMX & .95 & .41 \\
Perceived overqualification & .96 & .46 \\
Job satisfaction & .96 & .41 \\
\hline
\end{tabular}

Note. LMX = leader member exchange

Structural equation analysis produces fit parameters: significance $<0.001, \chi 2 / \mathrm{df}=1.98, \mathrm{RMR}=0.03, \mathrm{GFI}=0.91$, $\mathrm{AGFI}=0.85, \mathrm{NFI}=0.95, \mathrm{IFI}=0.98, \mathrm{TLI}=0.97, \mathrm{CFI}=0.98$, and RMSEA $=0,08$. Using this model, it can be concluded that only Hypothesis 3 and 6 rejected. The effect of the leader-member exchange on early retirement intention is actually significant, but this effect is actually positive, rejecting Hypothesis 3. Meanwhile, Hypothesis 1, Hypothesis 2, Hypothesis 4, and Hypothesis 5 are all accepted. The R square for the model is $15.4 \%$ for perceived overqualification, $66.9 \%$ for job satisfaction, and $10.1 \%$ for early retirement intention. These results indicate that $15 \%$ of the variance of perceived overqualification is explained by leader-member exchange. Meanwhile, $67 \%$ of the variance in job satisfaction is explained by leader-member exchange and perceived overqualification. For early retirement intention, $10 \%$ of this variable is explained by leader-member exchange, 
perceived overqualification, and job satisfaction. The model along with its specifications can be seen in the following table and figure.

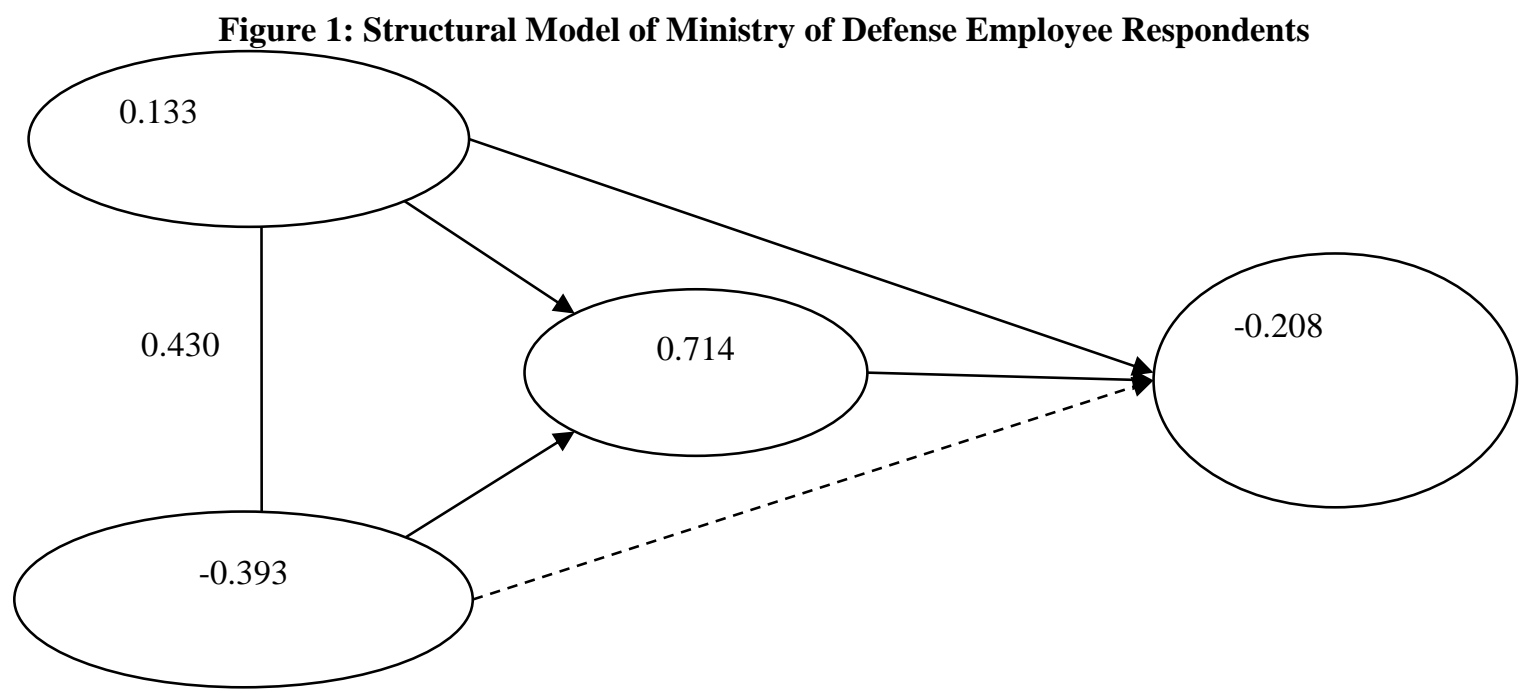

Note: all betas are significant except beta which links perceived overqualification with early retirement intention, marked by a dashed line

Table 3 Relationships between constructs

\begin{tabular}{lcccccc}
\hline Relationship & Loading Factor & Std. Error & t-value & p & Hypothesis & Result \\
\hline LMX $\rightarrow$ PO & $-0,393$ & 0,133 & $-4,56$ & 0,000 & H1 & Supported \\
\hline LMX $\rightarrow$ JS & 0,714 & 0,082 & 8,99 & 0,000 & H2 & Supported \\
\hline LMX $\rightarrow$ ERI & 0,430 & 0,280 & 2,57 & 0,010 & H3 & Not supported \\
\hline JS $\rightarrow$ ERI & $-0,418$ & 0,263 & $-2,58$ & 0,010 & H4 & Supported \\
\hline $\mathrm{PO} \rightarrow$ JS & $-0,208$ & 0,039 & $-3,60$ & 0,000 & H5 & Supported \\
\hline PO $\rightarrow$ ERI & 0,133 & 0,101 & 1,42 & 0,155 & H6 & Not supported
\end{tabular}

Note. $\mathrm{LMX}=$ leader member exchange, $\mathrm{PO}=$ perceived overqualification, JS = job satisfaction, ERI $=$ early retirement intention

In line with the results above, it can be seen which dimension most influences certain variables. Based on the factor loadings in the model, the dimensions of leader-member exchange that most influential in reducing perceived overqualification, increasing job satisfaction, and increasing early retirement intention are respect to leader professionalism (average loading factor 0.790). The most influential perceived overqualification dimension in reducing job satisfaction is higher education than required (average loading factor 0.877). The most influential dimension of job satisfaction in reducing early retirement intention is overall job satisfaction (average loading factor 0.826).

Because perceived overqualification does not significantly affect early retirement intention, the question arises whether this variable gives a significant effect on early retirement intention, but indirectly, namely through job satisfaction. To find out the significance of this effect, Sobel test, Aroaian test, and Goodman test were conducted (Preacher dan Leonardelli, 2019). Results showed the following values: Sobel Test $=2.09$ with a significance level of $\mathrm{p}=0.036<0.05$; Aroian test $=2.04$ with a significance level of $\mathrm{p}=0.041<0.05$; and the Goodman test $=2.15$ with a significance level of $p=0.031<0.05$. In all tests, the results obtained were significant, indicating that the effect of mediation was significant. These results indicate that job satisfaction mediates the effect of perceived overqualification on early retirement intention. Because the direct effect of perceived overqualification on early retirement intention is not significant, the effect that occurs is full mediation. Other mediating effects are reported in the following Table 4. The mediating role of job satisfaction on the influence of leader-member exchange on early retirement intention is partial mediation because the direct influence of the leader-member exchange on the early retirement intention is significant. The same applies to the influence of leader-member exchanges on job satisfaction.

Table 4 Results of mediation test 


\begin{tabular}{lcccc}
\hline Mediation relationship & Sobel test & Aroian test & Goodman test & Conclusion \\
\hline $\mathrm{LMX} \rightarrow$ ERI through JS & $-2,48^{*}$ & $-2,47^{*}$ & $-2,50^{*}$ & Partial mediation \\
\hline $\mathrm{PO} \rightarrow$ ERI through JS & $2,09^{*}$ & $2,04^{*}$ & $2,15^{*}$ & Full mediation \\
\hline $\mathrm{LMX} \rightarrow$ JS through PO & $2,80^{* *}$ & $2,76^{* *}$ & $2,85^{* *}$ & Partial mediation \\
\hline
\end{tabular}

Note: $* \mathrm{p}<0,05 ; * * \mathrm{p}<0,01 ; \mathrm{LMX}=$ leader member exchange, $\mathrm{PO}=$ perceived overqualification, $\mathrm{JS}=$ job satisfaction, ERI = early retirement intention

The direct influence and the indirect influence of leader-member exchange are different so that it is possible that if totaled, leader-member exchange can be negative, according to the hypothesis. This is if the strength of direct influence is weaker than indirect influence through job satisfaction. However, when compared between direct and indirect effects, the direct effect of leader-member exchange is stronger than the indirect effect through job satisfaction (see Table 5). As a result, the total effect of leader-member exchange is positive. In the other two relationships, direct influence is also stronger. But because both the direct and indirect effects are positive, the power of total influence is positive.

Table 5 Total relationship between constructs

\begin{tabular}{cccc}
\hline relationship & Direct effect & Indirect effect & Total effect \\
\hline $\mathrm{LMX} \rightarrow$ ERI & 0,430 & $-0,385$ & 0,046 \\
\hline $\mathrm{PO} \rightarrow$ ERI & 0,133 & 0,087 & 0,219 \\
\hline $\mathrm{LMX} \rightarrow \mathrm{JS}$ & 0,714 & 0,082 & 0,796 \\
\hline
\end{tabular}

Note: $\mathrm{LMX}=$ leader member exchange, $\mathrm{PO}=$ perceived overqualification, JS = job satisfaction, ERI = early retirement intention

\section{DISCUSSION}

Findings and Implications for Theory and Practice

Of the eight hypotheses that we have put forward, six hypotheses have received full support, while the remaining two are rejected. Even so, referring to the theory of early retirement from de Wind et al (2015), perceived overqualification and job satisfaction, which could be considered covered work ability, motivation, and opportunity, do indeed have an impact on early retirement intention.

Regarding leader member exchange, the results show that this variable leads to perceived overqualification and job satisfaction but also to early retirement intentions. The justification for the positive influence of the boss-subordinate exchange on turnover intention has recently been stated in the literature (Chen et al., 2018; Chen et al., 2015; Cobb dan Lau, 2015; Estel, Schulte, Spurk, dan Kauffeld, 2019; Fu, Flood, Rousseau, dan Morris, 2018; Lee, Thomas, Martin, dan Guillaume, 2019; S.-L. Li, Huo, dan Long, 2017; Martin, Thomas, Legood, dan Russo, 2018; Wang, Demerouti, Le Blanc, dan Lu, 2018; Yu, Matta, dan Cornfield, 2018). Martin et al., (2018) suggested that this negative effect can occur because of the leader-member exchange differentiation in the group. Differentiation between leader-member exchange is a situation where superiors build relationships with different qualities with each subordinate. This differentiation creates tension among subordinates because subordinates who have low quality relationships feel jealous of subordinates who have good quality relationships. This in turn creates a bad climate in the work group, splits group cohesion, and in turn makes employees who are seen to have good relations with superiors feel themselves too as 'golden children', making these employees want to immediately leave the organization to escape from the organization social pressure built up within the organization.

Regarding perceived overqualification, the insignificant influence between perceived overqualification with the intention to move to work indicates that perceived overqualification cannot be used as a direct predictor of early retirement intention. On the contrary, there is a mediator variable which is proven to link perceived overqualification with early retirement intention. The results of this study are consistent with several previous studies such as research conducted by Sim dan Lee (2018), Harari, Manapragada, dan Viswesvaran (2017), Ahmad dan Qadir (2018), Lee, Chou, dan Wu (2016), Debus, Gross, dan Kleinmann (2019), dan Yang, Guan, Lai, She, dan Lockwood (2015).

Finally, our findings provide practical implications. The Ministry of Defense needs to develop policies that can take advantage of the excessive qualifications of military employees for jobs that are wider or more complex than those currently given. For example, employees in the defense strategy sector can carry out more indepth and comprehensive research activities that involve military physical competence using experimental or observation/simulation methods to produce a more detailed defense strategy. This activity can increase enthusiasm or pride in functional employees in the Ministry of Defense and assist in producing better quality output. In addition, policies aimed at improving the quality of subordinate supervisors are needed to prevent early retirement effect from overqualification. This can prevent employees from retiring early, thereby maintaining the productivity of public services. 
In addition, this study contributes by looking at the vital impact of leader-member exchange on the intention to change employment. The findings of this study highlight leader-member exchange as an important antecedent for early retirement intention of employees with military background in civilian institutions. These employees are more loyal to the unity of the same fate. Therefore, leadership in civic institutions must involve an equality strategy to maintain harmony within the work group. Such a strategy includes equal and indiscriminate work and evaluation activities. Building leadership that treats subordinates equally is an important key for public institutions with military employees so that they can be loyal to the institution.

\section{LIMITATIONS AND FUTURE RESEARCH}

A number of limitations need to be considered in this study. First, this study uses a small number of samples. The number of samples in this study only reached 157 people. The researcher realized that this number was relatively small so that the conclusions from this study needed to be looked at with caution. However, this number is unavoidable because the sample group was active high-ranking military members who were difficult to approach and asked to fill in the questionnaire. In addition, the institution for the location of the study is a highstate institution that has large responsibilities and scope of work in one of the countries with the largest population in the world. Other quantitative research on early retirement even used a smaller sample size than this study as small as 27 respondents (Topa et al, 2018).

Another limitation is the view on the intention of early retirement. Some researchers argue that early retirement intention construct is different from the turnover intention construct (Adams \& Beehr, 1998). This study uses indicators from turnover intentions that were adapted to be indicators of early retirement intention so that it is considered the same between early retirement intentions and turnover intentions. However, Adams and Beehr (1998) state that both constructs can be treated equally in certain contexts. We believe that the context of our research allows both variables to be considered the same. This is because the research sample is old and have the opportunity to retire early. It doesn't make sense for these employees to have intentions to just stop working like the turnover intention concept. It makes more sense for them to choose an early retirement package that has been provided by the government.

Furthermore, there are also limitations related to research instruments. We use a modified instrument so that we get a large number of items for each study variable. This can be problematic with an ideal ratio of 10:1 for the number of samples compared to the number of items. However, the final analysis does not use a single indicator score but a composite score so that the use of large numbers of indicators is still permitted in small sample analyzes.

Regarding further research, our findings encourage the need for further research to ensure the suitability of current research results in different contexts. This research carried out in the context of public civil institutions with military employees. Different findings may be obtained from civil public institutions with civil servants or military institutions with military or civil servants. It will also be more convincing if further research uses a larger number of samples or more complex methods, including studies that are longitudinal in nature, to ascertain the relationship between the research variables.

\section{CONCLUSION}

This study provides an examination of the potential influence of LMX and perceived overqualification of military personnel in civil institutions to their job satisfaction and intention to retire early. Our findings suggest that while LMX has an effect on employee job satisfaction, LMX also have a positive impact on the intention to retire early. Meanwhile, perceived overqualification has a negative effect on job satisfaction. Job satisfaction variable mediate the effect of perceived overqualification and LMX on the intention to retire early.

\section{REFERENCES}

[1]. Adams, G. A., \& Beehr, T. A. (1998). Turnover and Retirement: a Comparison of their Similarities and Differences. Personnel Psychology, 51, 643-666.

[2]. Ahmad, H., \& Qadir, M. (2018). Dimensions of Perceived Over Qualification, Perceived Organizational Support and Turnover Intentions. Journal of Management and Human Resource, 1, 18-33.

[3]. Akuntono, I. (2015, November 2). Ini 10 Kementerian dengan Anggaran Tertinggi dalam APBN 2016 (These are 10 Ministries with Highest Budget in 2016 State Budget). Kompas.Com. Retrieved from https://nasional.kompas.com/read/2015/11/02/20094921/Ini.10.Kementerian.dengan.Anggaran.Tertinggi.d alam.APBN.2016

[4]. Al Sabei, S. D., Labrague, L. J., Ross, A. M., Karkada, S., Albashayreh, A., Al Masroori, F., \& Al Hashmi, N. (2020). Nursing Work Environment, Turnover Intention, Job Burnout, and Quality of Care: The Moderating Role of Job Satisfaction. Journal of Nursing Scholarship, 52(1), 95-104.

[5]. Azeez, R. O., Jayeoba, F., \& Adeoye, A. O. (2016). Job Satisfaction, Turnover Intention and Organizational Commitment. BVIMSR's Journal of Management Research, 8(2), 102-113. 
[6]. Benedict, J. N., Gayatridevi, S., \& Velayudhan, A. (2009). Perceived overqualification, job satisfaction, somatization and job stress of MNC executives. Journal of the Indian Academy of Applied Psychology, 35(2), 283-289. Retrieved from http://medind.nic.in/jak/t09/i2/jakt09i2p283.pdf

[7]. Bonke, T., Kemptner, D., \& Luthen, H. (2018). Effectiveness of early retirement disincentives: Individual welfare, distributional and fiscal implications. Labour Economics, 51, 25-37.

[8]. Breevaart, K., Bakker, A. B., Demerouti, E., \& van den Heuvel, M. (2015). Leader-member exchange, work engagement, and job performance. Journal of Managerial Psychology, 30(7), 754-770.

[9]. Bruck, C. S., Allen, T. D., \& Spector, P. E. (2002). The relation between work-family conflict and job satisfaction: A finer-grained analysis. Journal of Vocational Behavior, 60(3), 336-353. https://doi.org/10.1006/jvbe.2001.1836

[10]. Chen, X., He, W., \& Weng, L.-C. (2018). What Is Wrong With Treating Followers Differently? The Basis of Leader - Member Exchange Differentiation Matters. Journal of Management, 44(3), 946-971. https://doi.org/10.1177/0149206315598372

[11]. Chen, Y., Chen, Z. X., Zhong, L., Son, J., Zhang, X., \& Liu, Z. (2015). Social exchange spillover in leadermember relations: A multilevel model. Journal of Organizational Behaviour, 36, 673-697. https://doi.org/10.1002/job

[12]. Cobb, A. T., \& Lau, R. S. (2015). Trouble at the next level : Effects of differential leader - member exchange on group-level processes and justice climate. Human Relations, 68(9), 1437-1459. https://doi.org/10.1177/0018726714557873

[13]. de Wind, A., Geuskens, G. A., Ybema, J. F., Bongers, P. M., \& van der Beek, A. J. (2015). The role of ability, motivation, and opportunity to work in the transition from work to early retirement - testing and optimizing the Early Retirement Model. Scandinavian Journal of Work Environment Health, 41(1), 24-35. https://doi.org/10.5271/sjweh.3468

[14]. Debus, M. E., Gross, C., \& Kleinmann, M. (2019). The Power of Doing: How Job Crafting Transmits the Beneficial Impact of Autonomy Among Overqualified Employees. Journal of Business and Psychology, 115 .

[15]. Defense Minister of Indonesia. Keputusan Menteri Pertahanan No KEP/08/M/IX/2001 tentang Badan Pertimbangan Jabatan dan Kepangkatan Tingkat Departemen Pertahanan (Decree of the Minister of Defense No. KEP / 08 / M / IX / 2001 regarding the Department of Defense's Position and Rank) (2001). Indonesia.

[16]. Deng, H., Guan, Y., Wu, C. H., Erdogan, B., Bauer, T., \& Yao, X. (2018). A relational model of perceived overquali?cation: the moderating role of interpersonal in?uence on social acceptance. Journal of Management, 44(8), 3288-3310.

[17]. Dumani, S. (2016). Engaging overqualified employees: The role of job and nonwork crafting. Dissertation Abstracts International: Section B: The Sciences and Engineering. University of South Florida. Retrieved from http://ovidsp.ovid.com/ovidweb.cgi?T=JS\&PAGE=reference \&D=psyc13\&NEWS=N\&AN=201642143-063

[18]. Erdogan, B., \& Bauer, T. N. (2009). Perceived overqualification and its outcomes: The moderating role of empowerment. Journal of Applied Psychology, 94(2), 557-565. https://doi.org/10.1037/a0013528

[19]. Erdogan, B., Tomás, I., Valls, V., \& Gracia, F. J. (2018). Perceived overqualification, relative deprivation, and person- centric outcomes: The moderating role of career centrality. Journal of Vocational Behavior, 107, 233-245. https://doi.org/10.1016/j.jvb.2018.05.003

[20]. Estel, V., Schulte, E., Spurk, D., \& Kauffeld, S. (2019). LMX differentiation is good for some and bad for others : A multilevel analysis of effects of LMX differentiation in innovation teams. Cogent Psychology, 6(1), 1-17. https://doi.org/10.1080/23311908.2019.1614306

[21]. Feldman, D. C., Leana, C. R., \& Bolino, M. C. (2002). Underemployment and relative deprivation among re-ennployed executives. Journal of Occupational and Organizational Psychology, 75, 453-471. https://doi.org/10.1348/096317902321119682

[22]. Fine, S., \& Nevo, B. (2008). Too smart for their own good? A study of perceived cognitive overqualification in the workforce. International Journal of Human Resource Management, 19(2), 346-355. https://doi.org/10.1080/09585190701799937

[23]. Fornell, C., \& Larcker, D. F. (1981). Evaluating Structural Equation Models with Unobservable Variables and Measurement Error. Journal of Marketing Research, 18(1), 39-50.

[24]. Fu, N., Flood, P. C., Rousseau, D. M., \& Morris, T. (2018). Line Managers as Paradox Navigators : Balancing Consistency and Individual Responsiveness in HRM Implementation. Journal of Management, 1-31. https://doi.org/10.1080/09585192.2017.1375963

[25]. General Directorate of Budgeting. (2018). Informasi APBN 2018 (2018 Budget Information). Jakarta.

[26]. Government of Indonesia. Peraturan Pemerintah RI No 39 Tahun 2010 tentang Administrasi Prajurit Tentara Nasional Indonesia (Government Regulation No 39 of 2010 on Indonesian Military Personnel Administration) (2010).

[27]. Green, F., \& Zhu, Y. (2008). Overqualification, job dissatisfaction, and increasing dispersion in the returns 
to graduate education (Department of Economics Discussion Paper No. No. 08,03). Canterbury.

[28]. Han, G. H., \& Jekel, M. (2011). The mediating role of job satisfaction between leader-member exchange and turnover intentions. Journal of Nursing Management, 19, 41-49. https://doi.org/10.1111/j.13652834.2010.01184.x

[29]. Harari, M. B., Manapragada, A., \& Viswesvaran, C. (2017). Who thinks they're a big fi sh in a small pond and why does it matter? A meta-analysis of perceived overqualification. Journal of Vocational Behavior, 102(January), 28-47. https://doi.org/10.1016/j.jvb.2017.06.002

[30]. Hosoda, M. (2016). Perceived Underemployment, Perceived Accent Discrimination, and Job Attitudes Among Immigrants : The Mediating Role of Perceived Organizational Support. Journal of Organizational Psychology, 16(2), 11-28.

[31]. Hu, J., Bauer, T. N., Erdogan, B., Jiang, K., Liu, S., \& Li, Y. (2015). There Are Lots of Big Fish in This Pond: The Role of Peer Overqualification on Task Significance, Perceived Fit, and Performance for Overqualified Employees. Journal of Applied Psychology, 100(4), 1228-1238.

[32]. Huang, S., Chen, Z., Liu, H., \& Zhou, L. (2017). Job satisfaction and turnover intention in China. Chinese Management Studies.

[33]. Hwang, J., \& Bae, J. (2017). Influence of mental health nurses' moral distress and job satisfaction on turnover intention. Journal of Korean Academy of Psychiatric and Mental Health Nursing, 26(4), 325-332.

[34]. Johnson, W. R., Morrow, P. C., \& Johnson, G. J. (2002). An evaluation of a perceived overqualification scale across work settings. Journal of Psychology: Interdisciplinary and Applied, 136(4), 425-441. https://doi.org/10.1080/00223980209604169

[35]. Jyoti, J., \& Bhau, S. (2015). Impact of Transformational Leadership on Job Performance : Mediating Role of Leader - Member Exchange and Relational Identification. SAGE Open, 1-13. https://doi.org/10.1177/2158244015612518

[36]. Kawai, N., \& Mohr, A. (2017). How Does Perceived Underemployment Influence Expatriate Job-Related Outcomes? A Moderated Mediation Study. The International Journal of Human Resource Management, 28, $1-27$.

[37]. Kulkarni, S., \& Ramamoorthy, N. (2014). Intra-firm transfer of best practices in moral reasoning: A conceptual framework. Business Ethics, 23(1), 15-33. https://doi.org/10.1111/beer.12035

[38]. Lee, A. J. R., Thomas, G., Martin, R., \& Guillaume, Y. (2019). Leader-member exchange (LMX) ambivalence and task performance: The cross- domain buffering role of social support. Journal of Management, 45(5), 1927-1957.

[39]. Lee, D.-C., Hung, L.-M., \& Chen, M.-L. (2012). Empirical Study on the Influence among Corporate Sponsorship, Organizational Commitment, Organizational Cohesiveness and Turnover Intention. Journal of Management and Sustainability, 2(2). https://doi.org/10.5539/jms.v2n2p43

[40]. Lee, H.-M., Chou, M.-J., \& Wu, H.-T. (2016). The Measurement Of Perceived Overqualification And The Relationships Among Perceived Overqualification, Psychological Empowerment, Job Satisfaction Of Private Kindergarten Teachers. European Journal of Research in Social Sciences, 4(8), 1-15.

[41]. Lee, S., \& Whitford, A. B. (2007). Exit, voice, loyalty, and pay: Evidence from the public workforce. Journal of Public Administration Research \& Theory, 18(4), 647-671.

[42]. Li, L., Zhu, Y., \& Park, C. (2018). Leader-Member Exchange, Sales Performance, Job Satisfaction, and Organizational Commitment Affect Turnover Intention. Social Behavior and Personality, 46(11), 19091922.

[43]. Li, S.-L., Huo, Y., \& Long, L.-R. (2017). Chinese Traditionality Matters: Effects of Differentiated Empowering Leadership on Followers' Trust in Leaders and Work Outcomes. Journal of Business Ethics, 145(1), 81-93.

[44]. Liao, C., Wayne, S. J., Liden, R. C., \& Meuser, J. D. (2017). Idiosyncratic deals and individual effectiveness : The moderating role of leader-member exchange differentiation. The Leadership Quarterly, 28(3), 438-450. https://doi.org/10.1016/j.leaqua.2016.10.014

[45]. Liden, R. C., \& Maslyn, J. M. (1998). Multidimensionafity of Leader-Member Exchange: An Empirical Assessment through Scale Development. Journal of Management, 24(1), 43-72. https://doi.org/10.1177/014920639802400105

[46]. Liu, S., \& Wang, M. (2012). Perceived overqualification: A review and recommendations for research and practice. In The Role of the Economic Crisis on Occupational Stress and Well Being: Research in Occupational Stress and Well Being (Vol. 10, pp. 1-42). Emerald Group Publishing Ltd. https://doi.org/10.1108/S1479-3555(2012)0000010005

[47]. Martin, R, Guillaume, Y., Thomas, G., Lee, A., \& Epitropaki, O. (2016). Leader-member exchange (LMX) and performance : a meta-analytic review. Personnel Psychology, 69(1), 67-121.

[48]. Martin, Robin, Thomas, G., Legood, A., \& Russo, S. Dello. (2018). Leader - member exchange (LMX) differentiation and work outcomes : Conceptual clarification and critical review. Journal of Organizational Behavior, 39, 151-168. https://doi.org/10.1002/job.2202 
[49]. Maynard, D. C., Joseph, T. A., \& Maynard, A. M. (2006). Underemployment, job attitudes, and turnover intentions. Journal of Organizational Behaviour, 27, 509-536.

[50]. Meng, F., \& Wu, J. (2015). Merit Pay Fairness, Leader-Member Exchange, and Job Engagement: Evidence From Mainland China. Review of Public Personnel Administration, 35(1), 47-69. https://doi.org/10.1177/0734371X12453057

[51]. Ministry of Defense Personnel Bureau. (2018). Indonesian Ministry of Defense Turnover 2013-2018. Jakarta.

[52]. Ministry of Internal Affairs. (2017). Ini Hasil Evaluasi Kementerian-Lembaga, Siapa Dapat Rapor Merah ? (This is the Results of Ministries-Institutions Evaluation, Who Got the Red Notes?). Retrieved July 27, 2018, from http://keuda.kemendagri.go.id/berita/detail/3291-ini-hasil-evaluasi-kementerian-lembaga-siapadapat-rapor-merah

[53]. Peraturan Presiden RI No 58 Tahun 2015 tentang Kementerian Pertahanan. Peraturan Presiden RI No 58 Tahun 2015 tentang Kementerian Pertahanan.

[54]. Preacher, K. J., \& Leonardelli, G. J. (2019). Calculation for the Sobel test: An interactive calculation tool for mediation tests. Retrieved July 14, 2019, from http://quantpsy.org/sobel/sobel.htm

[55]. Presiden RI. Inpres No 4 Tahun 2016 tentang Langkah-Langkah Penghematan dan Pemotongan Belanja Kementerian/Lembaga dalam Rangka Pelaksanaan Anggaran Pendapatan dan Belanja Negara Tahun Anggaran 2016 (2016).

[56]. Purnamasari, D. (2017). Efektifkah Layanan Publik PNS? Retrieved July 27, 2018, from https://tirto.id/efektifkah-layanan-publik-pns-cwlh

[57]. Robbins, S. P., \& Judge, T. A. (2017). Organizational Behavior (Seventeent). Boston: Pearson.

[58]. Santoso, A. (2018). Mengurai Problem Surplus Kolonel di Tubuh TNI (Analyzing Colonel Surplus Problem in Indonesian Military Body). Retrieved May 29, 2019, from https://tirto.id/mengurai-problem-surpluskolonel-di-tubuh-tni-cNqU

[59]. Shah, J., \& Lacaze, D. (2018). Moderating role of Cognitive Dissonance in the relationship of Islamic work ethics and Job Satisfaction, Turnover Intention \& Job Performance To cite this version : HAL Id: hal01901056. In 29ème Congrès AGRH. Lyon, France.

[60]. Shu, X., Gong, Y., Xiong, J., \& Hu, X. (2018). Job Satisfaction, Turnover Intention and Work Performance in Chinese Family Enterprises. Management International, 22(2), 84-95.

[61]. Sim, Y., \& Lee, E. (2018). Perceived underqualification and job attitudes: the role of transformational leadership. Leadership \& Organization Development Journal, 39(8), 962-974. https://doi.org/10.1108/LODJ-03-2018-0127

[62]. Topa, G., Depolo, M., \& Alcover, C. M. (2018). Early Retirement : A Meta-Analysis of Its Antecedent and Subsequent Correlates. Frontiers in Psychology, 8, 2157.

[63]. Wang, H., Demerouti, E., Le Blanc, P., \& Lu, C. (2018). Crafting a job in ' tough times ': When being proactive is positively related to work attachment. Journal of Occupational and Organizational Psychology, 91, 569-590. https://doi.org/10.1111/joop.12218

[64]. Wang, W., Newman, D. A., \& Dipboye, R. L. (2016). Social Network Contagion in the Job SatisfactionIntention-Turnover Model. In Academy of Management Proceedings (p. 17930). Briarcliff Manor, NY: Academy of Management.

[65]. Wu, C., Odden, M. C., Fisher, G. G., \& Stawski, R. S. (2016). Association of retirement age with mortality : a population-based longitudinal study among older adults in the USA. Journal of Epidemiology and Community Health, 70, 917-923. https://doi.org/10.1136/jech-2015-207097

[66]. Yang, W., Guan, Y., Lai, X., She, Z., \& Lockwood, A. . (2015). Career adaptability and perceived overqualification: Testing a dual-path model among Chinese human resource management professionals. Journal of Vocational Behavior, 90, 154-162.

[67]. Yeo, M., Ananthram, S., Teo, S. T. T., \& Pearson, C. (2015). Leader-Member Exchange and Relational Quality in a Singapore Public Sector Organization. Public Management Review, 17(10), 1379-1402.

[68]. Yu, A., Matta, F. K., \& Cornfield, B. (2018). Is LMX Differentiation Beneficial or Detrimental for Group Effectiveness? A Meta-Analytic Investigation and Theoretical Integration. Academy of Management Journal, 61(3), 1158-1188. https://doi.org/10.5465/amj.2016.1212 